\title{
The Role of Skadron-12/Serbu Puspenerbad in Supporting Gatot Soebroto Airport Activation
}

\author{
Elfaz Faqih Aulia ${ }^{1}$, Armaidy Armawi ${ }^{1 *}$, Joko Waluyo ${ }^{2}$, Darto Wahidin ${ }^{1}$ \\ ${ }^{1}$ Study Program of National Resilience, The Graduate School of Universitas Gadjah Mada, Indonesia \\ ${ }^{2}$ Department of Mechanical and Industrial Engineering, Faculty of Engineering, Universitas Gadjah Mada, Indo- \\ nesia
}

*Corresponding author:

E-mail:

armaidy@ugm.ac.id

\begin{abstract}
The paper purpose is to describe the roles, challenges, and strategies of Skadron12 or Serbu Puspenerbad in supporting the activation acceleration of Gatot Soebroto Airport in the Way Kanan Regency, Lampung. Skadron-12 or Serbu Puspenerbad must pay attention to the improvement system as mandatory. The security of the Gatot Soebroto Airport area in Way Kanan Regency must provide significant advantages. The need for existing human resources in Indonesia plays a vital role in maintaining the defense force and overcoming national problems. The presence of Skadron-12 or Serbu Puspenerbad in support of the Gatot Soebroto Airport activation. Part of Tentara Nasional Indonesia preparedness in handling potential national crises. Considering Indonesia's geography condition as an archipelagic nation, the Skadron-12 or Serbu Puspenerbad mode upgrading is necessary to empower the defense area. Such as the one at Gatot Soebroto Airport in Way Kanan Regency, Lampung. Activation upgrading support at Gatot Soebroto Airport is also can be used to address other non-military threats. The obstacles faced by Skadron-12 or Serbu Puspenerbad in the activation effort of Gatot Soebroto Airport, including lack of equipment quality and availability, ideal-deviated flight conditions phenomena and problems, and low intensity in infrastructure maintenance. Hence, strategies used to support activation acceleration implementation involve three things. Those are knowledge improvement of flight safety procedures, flight safety procedures supporting training development, and flight safety procedures supporting facility updates. Thus, the formed strategy development was operated to answer every obstacle and aviation problem faced by Skadron-12 / Serbu Puspenerbad in Gatot Soebroto Airport activation located in Way Kanan Regency, Lampung.
\end{abstract}

Keywords: Role, skadron-12 or serbu puspenerbad, airport

\section{Introduction}

The squadron/skadron has a critical duty to manage Flight Schools, Flight Instructor School, Navigator Instructor School, and prepare flight crews or instructors. Skadron-12/Serbu Puspenerbad is used to expand the actuation and firepower of the Indonesian Army Combat Units in War Military Operations and Non-War Military Operations. Skadron-12/Serbu Puspenerbad is under the Army Aviation Center control based at Gatot Soebroto Airport, Way Kanan Regency, Lampung.

Tentara Nasional Indonesia (TNI), the principal component of national defense, has the main task of upholding state sovereignty, maintaining the Indonesia territorial integrity based on Pancasila and the 1945 Constitution, and protecting the entire nation and homeland from threats and disturbances of the national integrity as stated in Law Number 34 of 2004 concerning Tentara Nasional Indonesia. Its tasks are mandated for every dimension of the force, such as army, navy, or air forces. 
Regarding the Preamble of the 1945 Constitution, Indonesia's national purposes are to protect the entire Indonesian nation and to promote public welfare, educate the nation's life and participate in carrying out world order based on independence, eternal peace, and social justice. Tentara Nasional Indonesia involves in realizing the national purpose. One of its critical components is the Indonesian Air Force. It used a hierarchy command system from the central commando down to the subordinates. Tentara Nasional Indonesia (TNI), the principal component of national defense, has the main task of upholding state sovereignty, maintaining the Indonesia territorial integrity based on Pancasila and the 1945 Constitution, and protecting the entire nation and homeland from threats and disturbances of the national integrity (Arfianto, 2018). Indonesia's condition as an archipelagic country, typical modes of transportation such as ships and aircraft are needed to connect between islands. Thus, the Indonesian Air Force has a vital task to build and develop the power of the air force. It also carries out the duty to implement air defense areas empowerment.

Based on Law Number 1 of 2009 concerning Aviation, the definition of Airports and Air Bases are abbreviated as Lanud. The Airport is an area on land and/or waters with certain boundaries that are used for aircraft landing and taking off, boarding and dropping passengers, loading and unloading goods, and places inter-mode transportation, which provide aviation safety and security facilities, as well as basic facilities and other supporting facilities. It is undeniable, the phenomenon of aviation accidents is a critical task to control immediately. As non-underestimated things, aviation accidents need prevention effort. It also reminds us that its workloads have a high potential risk as well. Hence, various flight accidents are not only creating material losses but also damaging crew-involved psychological conditions.

The Regional Government of Way Kanan Regency had signed a Memorandum of Understanding between the Indonesian Army, the Ministry of Transportation of the Republic of Indonesia, the Regional Government of Lampung Province regarding the Joint Use of the Gatot Soebroto Army Air Base for Civil Airports in Way Kanan Regency, Lampung Province. Cooperation signed is to support the ease of shared access, not only for the Army and Regional Governments but also for the local community (Senayanpost.com, 2021). Thus, the impact can accelerate the regional development of the Way Kanan Regency as several regencies on the border of Lampung Province and South Sumatra Province. Gatot Soebroto Air Base utilized as Skadron-12/Serbu Puspenerbad base under the control of the Army Aviation Center. Currently, Gatot Soebroto Airport is managed by the government not only for the matter of national defense. It transformed into a vital transportation facility for the community, local government, and the business world.

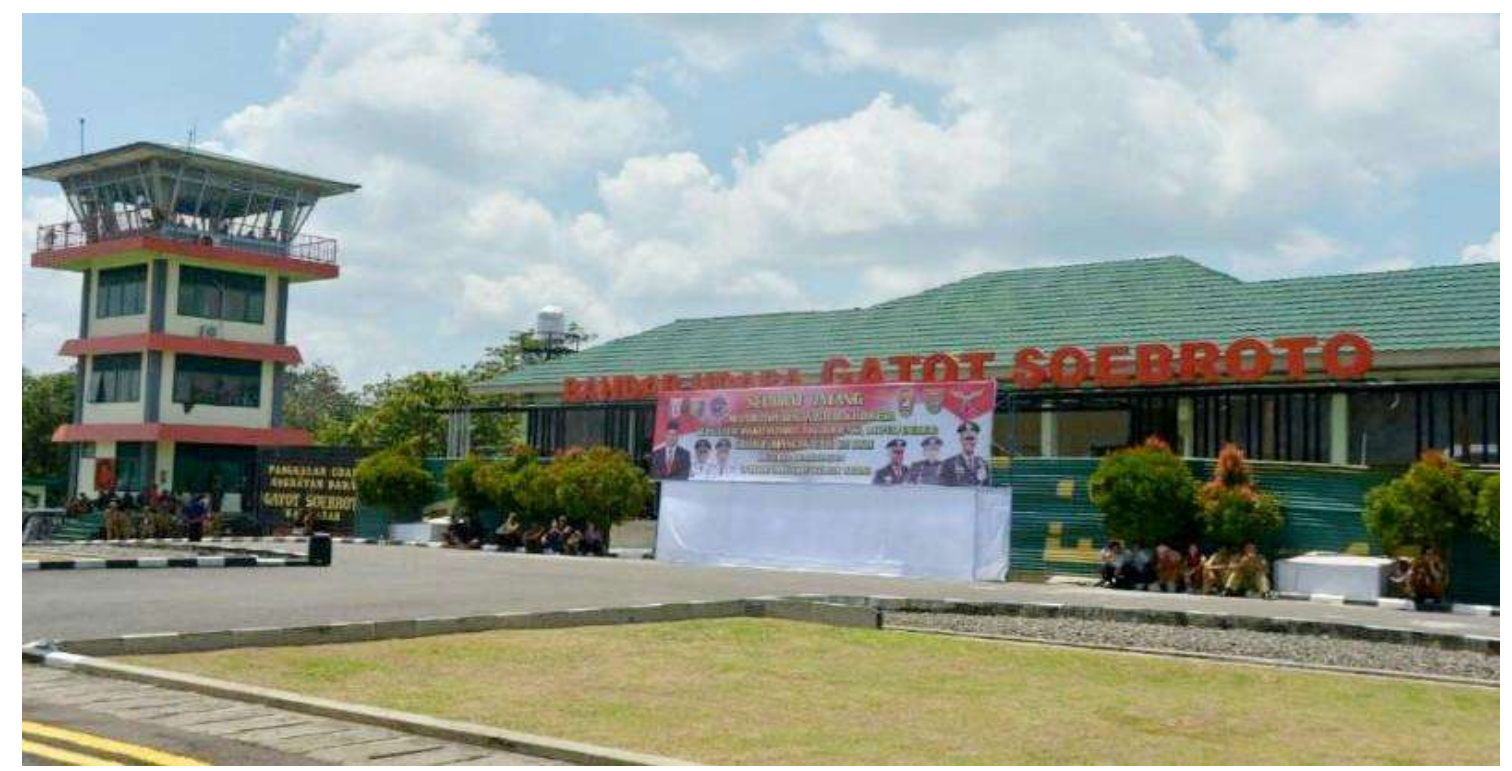

Figure 1. Gatot Soebroto Airport in Way Kanan Regency (Sources: lampungpro.co, 2019) 


\section{Material and Methods}

This research uses a descriptive qualitative approach. Sources of research data come from primary and secondary data. The research location of Skadron-12/Serbu Puspenerbad of Gatot Soebroto Aiport in Way Kanan Regency, Lampung. The process of collecting data is obtained by observation, interviews, and documentation. After collecting data, data analysis is carried out by reducing the data obtained, then the data is presented in narrative form, and drawing conclusions and recommendations to related parties.

\section{Results and Discussion \\ Role of Skadron-12/Serbu Puspenerbad}

According to Soekanto, the role is a dynamic process of position (status). If a person carries out his rights and responsibility according to his position, then he has carried out a role. Both cannot be separated because the one depends on the other and vice versa (Soekanto, 2009). It relates to its technical function role in handling operational missions as supporting the application of the assignment from Skadron Udata 8's helicopter unit. These operations support roles include airlift support operations, air medical evacuation operations, and Combat Search and Rescue operations. The involvement of the Air Force helicopter squadron is like a joint operation with other force dimensions in the context of Under the Operation Command (Setiawan, 2018). One of the involvements of the Indonesian Air Force in the Operation of Security in Vulnerable Areas in Indonesia is to deploy a squadron of helicopters in the form of defense equipment and other elements to accelerate the activation of Gatot Soebroto Airport in Way Kanan Regency, Lampung.

In addition, the ability of potential human resources is also necessary. This effort is an effective instrument of state power (Sebastian, 2015). As well as the requirements to prepare excellent human resources for flights in Indonesia. Therefore, human resources have a critical role in the Skadron12/Serbu Puspenerbad development at Gatot Soebroto Airport, Way Kanan Regency, Lampung. According to Badan Pusat Pendidikan Penerbang Angkatan Darat (PUSDIK PENERBAD), the requirements to become an Indonesian Army pilot are (Rani et al., 2016): (1) Military aviation only accepts from science-based high school graduates; (2) candidate's leg length the at least $100 \mathrm{~cm}$ from the hip; (3) passing medical tests including heart, eyes, and others; (4) having an average English proficiency; and (5) mathematical and physical calculations quick solver. After passing all the requirements above, prospective students will be invited to fly by the instructor to find out whether students are afraid of height or not. As well as students' motor nerves, whether students are responsive to problems that are given by instructors to prospective pilots or not. Then, student talent for flying.

Tim Prior and Florian Roth said, "cities must acknowledge the limits of disaster prediction and prevention. New approaches to disaster risk assessment should permit management processes to adapt to changing risks and new risk environments. Among such adaptation measures are efforts to increase the flexibility of response and the longitudinal nature of disaster recovery. Initiatives that focus on fostering the self-efficacy of communities, or that strengthen existing networks between actors involved in disaster management across administrative and territorial boundaries are represented in this context" (Prior \& Roth, 2013). Thus, disaster management can be carried out through the role of the organization. However, prevention is also needed through a risk management approach in Skadron12/Serbu Puspenerbad.

In addition to strengthening human resources, military logistics also plays an important role. Military logistics is the process of planning foodstuffs and services to meet the needs of military forces (Hutri et al., 2020). The advantage in implementing logistical support is not only in the form of a financial benefit but also in other benefits. The main tasks are implemented effectively and efficiently as a benefit of material support and facilities. Human resource planning is the analyzing and identifying process about the human resource needed for the organization to achieve its goals (Badriyah, 2017). The realization of professional soldiers requires careful planning and management of human resource 
development. On the other hand, facilities are everything that helps efforts and work to achieve particular goals.

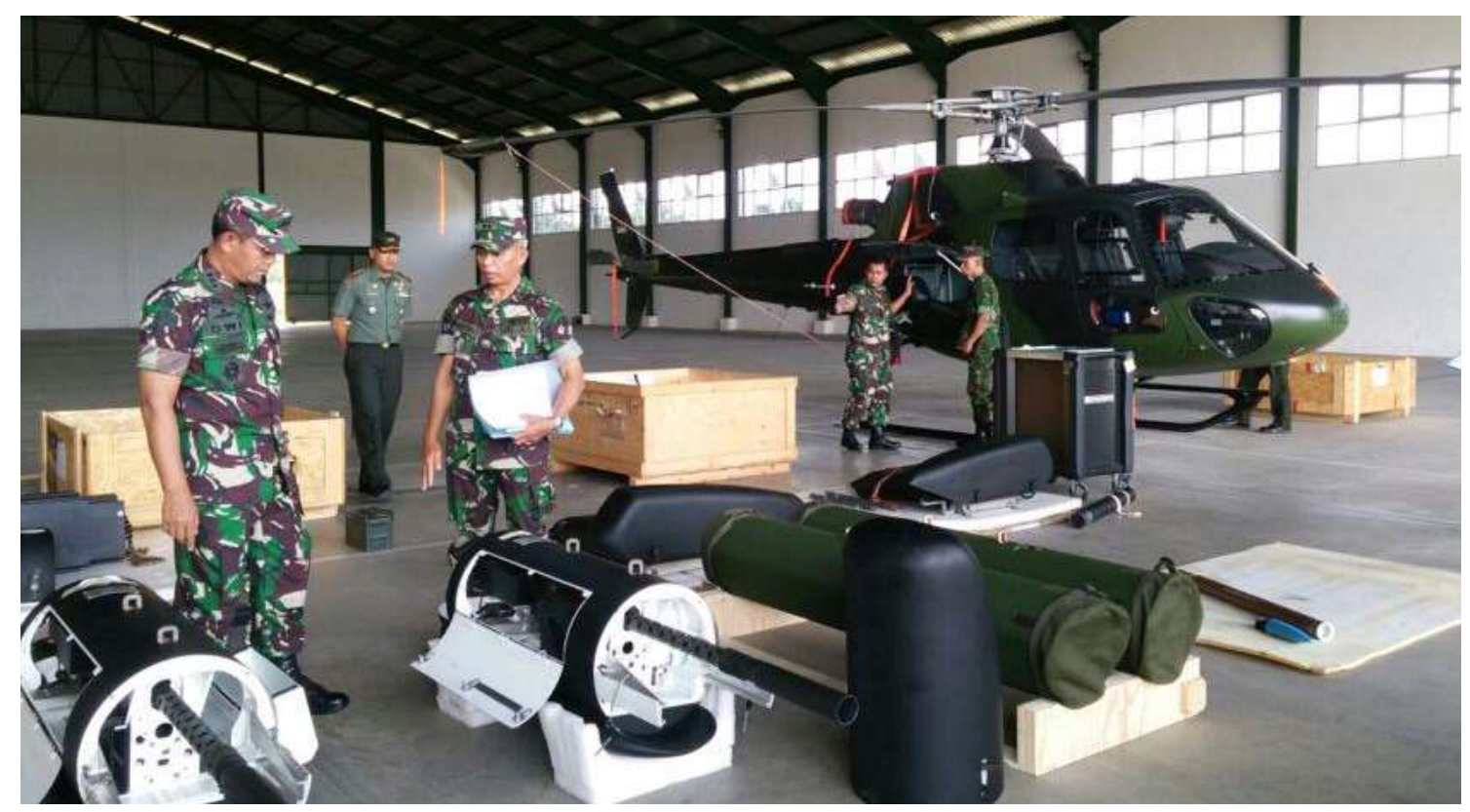

Figure 2. Logistic Distribution of Fennect Helicopter in Markas Komando Skadron-12/Serbu Way Tuba (Sources: Lampost.co., 2018)

As reported by Lampost.co (01/03/2018), Markas Komando Skadron-12/Serbu Way Tuba has received five helicopters of the Attack Fennec type AS 550 C3. The logistic process of Fennec type helicopter begins from the Ministry of Defense of the Republic of Indonesia. Then, it gave to Indonesia Army Headquarters to distribute to Markas Komando Skadron-12/Serbu Way Tuba, Way Kanan Regency. The complexity of national defense issues and increasingly diverse forms. The development of threats from various parties. Both external and internal threats require potential and reliable human resources. Excellent human resources play role in the improvement of defense policymaking or implementation. Currently, Indonesia can not only prioritize armed forces in maintaining its sovereignty. Therefore, human resources are expected to be able to master the technology and capabilities of various resources in managing national defense, especially in utilizing the role of national resources in maintaining air defense.

The role of Skadron-12/Serbu Puspenerbad in supporting the activation of Gatot Soebroto Airport is critical. Considering the Indonesia geography condition which consists of thousands of islands, it is necessary to increase the Skadron-12/Serbu Puspenerbad mode at Gatot Soebroto Airport to empower the defense area. This strength is the pride of the nation. It is ready to provide access from one region to another. Then, it helps to defend the Indonesian territory as well. Skadron-12/Serbu Puspenerbad is not only operated during warfare or territory defending. However, activation at Gatot Soebroto Airport can be used to address non-military threats, such as assisting local governments in conflict management, overcoming COVID-19, natural disasters, and various problems of difficulty in accessing certain areas.

\section{Obstacles Faced by Skadron-12/Serbu Puspenerbad}

Military aviation has advantages in the field of defense and security. This task is mandated by the Tentara Nasional Indonesia. The use of helicopter defense equipment is a perfect choice in carrying out operations in vulnerable areas where terrain conditions are often not easy. It can fly agile in terrain 
with difficult natural obstacles. It is easy to get into hilly crevices. This ability is based on the characteristics of helicopters which are more flexible than fixed-wing aircraft.

Obstacles faced by Skadron-12/Serbu Puspenerbad are things that must be overcome by the stakeholder and related institutions. Thus, Skadron-12/Serbu Puspenerbad can survive in carrying out its roles and functions properly. These obstacles are the condition of stakeholders who are experiencing challenges. Then, the decline of both the existence of Skadron-12/Serbu Puspenerbad and Gatot Soebroto Airport activation. This issue should be overcome in priority. The following are the obstacles faced by Skadron-12/Serbu Puspenerbad in the activation of Gatot Soebroto Airport.

First, the lack of equipment quality and availability. Because the flight unit capability is related to pilot training, the technology issue in the Skadron-12/Serbu Puspenerbad is something that must be overcome by stakeholders and institutions, as well as supporting equipment for carrying out the operated mission (Setiawan, 2018). Thus, equipment updates can be applied optimally and the operation mission goal can be carried out safely, effectively, and efficiently. In addition, there are some ability gaps related to pilot experience and the activation system that hasn't been used optimally. Therefore, other required types of equipment were not supported well by stakeholders and related institutions. Cardi explains that "developing resilience complements measures to achieve critical infrastructure protection, which is more relevant to their physical protection, and must be seen as a component of a more complex system that targets a much wider area and more actors, each with its features and with own vulnerabilities and strong points". The defense system equipment development is complex, especially in targeting the defense area. Thus, it is urgent to develop the defense area resilience through the infrastructure system. Meanwhile, Skadron 12/Serbu Puspenerbad has the opportunity to play a role in supporting the Indonesian defense area resilience.

Second, the facts show that some phenomena and problems deviate from ideal flight conditions has happened. It is related to combat readiness, such as decreased motivation to work outside the Homebase, violations of discipline on duty, decreased levels of loyalty to colleagues and others (Arfianto, 2018). Skadron Udara 15 involves the role of defense equipment and personnel in its operational activities so that the achievement of tasks that are following the targets can be realized. Success in achieving the tasks assigned to each unit will be important in achieving the success of the tasks of the Indonesian Air Force in general. Achieving the success of the task will be influenced by one of the factors that become the decisive point anytime and anywhere.

Third, the lack of regular and routine infrastructure maintenance. Irregular maintenance is a threat in aviation. Some of the countermeasures against aircraft hijacking have been done, although not optimal yet. Moreover, at this time there are no other special units trained to deal with aircraft hijacking at each of the existing air bases in Indonesia, while the potential threat of aircraft hijacking can still occur in various regions (Butarbutar et al., 2018). Thus, there has not been a cooperative relationship and synergy between the base work unit and competent stakeholders. So, if a similar incident occurs, it can pose a danger that the threat level will be greater, not only for the flight crew but also for the community in the area.

In the future, Skadron 12/Serbu Puspenerbad must be more agile to involve the mastery of more modern technology and balanced with excellent and potential human resources in Indonesia. Various forms of threats are no longer in the form of state actors, but also involve non-state actors. Guerrillas and militias threat form who attack the heart of a country's defense quickly (Sebastian, 2015). Therefore, building defense forces must adapt to existing developments starting from now in various innovations.

\section{Strategy to Support the Implementation of Activation Acceleration}

The Air Force is an integral part of the Tentara Nasional Indonesia in national defense efforts. Strengths and capabilities development in purpose to carry out its roles and functions. It also helps to carry out duties both in the national defense system and assisting the government to face uncertain 
conditions, such as natural disasters and existing conflict problems. Thus, a strategy is needed to support the implementation of activation acceleration, both in technological innovation and continuous maintenance.

The gradual and sustainable modernization of defense equipment is the core strategy in the implementation of activation acceleration. Thus, modernization must be balanced with increasing the capacity of human resources for the crew of Skadron 12/Serbu Puspenerbad. The ability of personnel still needs improvement, both in technology and other resources (Minarno et al., 2018). For this reason, the education and training currently being held must be adequate. Personnel capacity development can be obtained through standardized education and training. Obtained innovations in science and technology must be applied immediately, both through education and increasing succession in supporting the activation of Gatot Soebroto Airport.

The low level of education requires serious attention. Personnel should competent both technically and tactically. The ability to operate modern equipment must continue to be mobilized. All the equipment ability can be used properly. Those are needed because the condition of personnel capabilities also impacts increasing the technical readiness of aircraft and optimizing the implementation of tasks carried out according to existing functions.

Then, the budget support is vital for supporting the implementation of education and training to improve the quality of qualified personnel (Butarbutar et al., 2018). In terms of budgeting, it will support Skadron 12/Serbu Puspenerbad to fulfilled their task to maintain the security and Gatot Soebroto Airport activation. So, their role in dealing with the threat of aircraft hijacking can be optimized.

The development of aviation science and technology also affects the implementation of logistical support. Thus, the activation of Gatot Soebroto Airport also requires logistical support in electricity and telecommunications services (Hutri et al., 2020). Because of the excellent level of expertise, it is possible to obtain better regional logistics support. Maintenance logistics support can be implemented through the support of airpower characteristics that require special handling.

Based on the reviews above, the strategies used to support the activation acceleration include:

- First, knowledge improvement of flight safety procedures. The pilot and crew should be checked and well-briefed before flights. During the flight, the crew has a well-coordinated condition and informing the passengers to obey safety procedures. Good communication skills are needed by the stakeholders of Skadron 12/Serbu Puspenerbad in supporting the activation of Gatot Soebroto Airport in Lampung. Communication skills can be applied in all aspects of components, both managers, Air Force, government officials in the region, and the community. So, a reciprocal relationship can arise and create a sense of security, comfort, and better service.

- Second, the development of training that supports the implementation of flight safety procedures. Various things need to be done, such as night flight training, emergency drills, exercises that are a test for personnel who have just finished their education, training for pilots to improve flight quality, and so on.

- Third, updating the facilities used in the implementation of flight safety procedures, such as flight manuals, live vests, life craft, fire extinguishers, emergency doors, safety belts, glass breaker tools or hammers, and first aid kits. The rest of the condition of the facilities and supporting facilities must be available and sufficient, and in good condition or suitability for use.

The development of the defense industry is the key to empowering the air defense area. Skadron $12 /$ Serbu Puspenerbad is a concrete effort in this field. Do not let the Indonesian people always be dependent on foreign powers, which creates a dilemma of national defense security issues. Future efforts need to break this dependence. But, without being followed by the development of the defense industry, which will result in the weakening of Indonesia's defense posture and capability, as the air issue. 
The performance improvement of pilots in supporting the activation of Gatot Soebroto Airport is quite good. But, Skadron 12/Serbu Puspenerbad needs to improve the knowledge capabilities and support equipment for pilots when facing work. In addition, Gatot Soebroto Airport needs to secure and maintain pilots to exceed the standards, both nationally and internationally (Sofyan et al., 2018). Adding flight training slots outside Gatot Soebroto Airport also can be done. So, the competence of the Indonesian Air Force flight crew also has a direct and significant effect on the performance of Skadron 12/Serbu Puspenerbad in the activation of Gatot Soebroto Airport.

However, it is necessary to pay attention to the condition of the Indonesian territory which is open and accessible from various directions containing risk and vulnerabilities so that the intensity of emerging threats becomes relatively higher. Thus, the Indonesian state seeks to ward off all threats by using all the instruments of its national power and realizing a strong national defense. In terms of improving scientific and technological innovation continuously, as well as strategies for Skadron 12/Serbu Puspenerbad at Gatot Soebroto Airport, Way Kanan Regency, Lampung.

\section{Conclusion}

The Air Force as an integral part of the Tentara Nasional Indonesia takes an active role in national defense efforts where the Air Force is tasked with enforcing the law and maintaining security in the airspace of national jurisdiction by ratified national and international laws. The implementation of the Air Forces duties is manifested in air operations. The synergy between the Indonesian Air Force and the Lampung government in the presence of Gatot Soebroto Airport is a manifestation in the context of tackling actions on security and air transportation problems so that they can be established and implemented. It is not only limited to coordination but also needs to be implemented in the form of field training. The Indonesian Air Force in carrying out air operations is very dependent on the readiness of the main weapons system (defense equipment) it has. Defense types of equipment owned by the Indonesian Air Force are aircraft, radar, and missiles.

Realization of support for the Gatot Soebroto Airport activation by looking at the real plan for the formation of Skadron 12/Serbu Puspenerbad. An innovation that must be supported by all parties. All threats, disturbances, obstacles, and challenges will always arise both from inside and outside, so prevention is required. In terms of aviation, the national defense faces uneasy challenges, because Indonesia is a country consisting of various islands. So, the role of the state is critical to raise awareness of the support for the Gatot Soebroto Airport activation, one of which is by implementing a strategy and answering every obstacle faced to answer all aviation problems through the strategic role of Skadron 12/Serbu Puspenerbad in the activation of Gatot Soebroto Airport in Way Kanan Regency, Lampung.

\section{Acknowledgment}

I would like to deliver my greatest gratitude to the Rector of Universitas Gadjah Mada, Dean of the Graduate School of Universitas Gadjah Mada, Study Program of National Resilience, the Graduate School of Universitas Gadjah Mada, who had supported this study directly, the Skadron12/Serbu Puspenerbad in the activation of Gatot Soebroto Aiport in Way Kanan Regency Lampung, who had allowed me to conduct this study, and the committee of International Conference of Social Research with Multidisciplinary Approach (ICSRMA) 2021 who had allowed me to participate in this conference.

\section{References}

Adriyah, M. (2017). Manajemen sumber daya manusia. Bandung: CV Pustaka Setia.

Arfianto A (2018) Pengaruh kompetensi dan lingkungan kerja terhadap combat readiness personel skadron udara 15 Wing Udara 3 di Lanud Iswahjudi Madiun. Jurnal Strategi Pertahanan Udara, 4, 63-86.

Butarbutar, S., Swastanto, Y., \& Barnas, R. (2018). Pemberdayaan personel Lanud Adisutjipto dalam rangka kesiapan penanggulangan aksi bajak udara. Jurnal Strategi Pertahanan Udara, 4(3), 23-40.

Hutri, D., Sitorus, H., \& Snatosa, A. I. (2020). Analisis dukungan logistik wilayah operasi udara di Pangkalan TNI Angkatan Udara Roesmin Nurjadin Pekanbaru. Jurnal Strategi Pertahanan Udara, 6(1), 65-80. 
lampungpro.co. (2021). Bandara Gatot Subroto Way Kanan Diusulkan Ganti Nama, Ini Calon Nama Barunya <https://lampungpro.co/post/23019/bandara-gatot-subroto-way-kanan-diusulkan-ganti-nama-ini-calon-nama-barunya>, accessed on $03 / 07 / 2021$.

Law Number 1 Year 2009 concerning Aviation.

Law Number 34 of 2004 concerning Tentara Nasional Indonesia.

m.lampost.co. (2021). Skadron-12 Way Tuba Uji Helikopter Serbu Fennec AS 550 C3 <https://m.lampost.co/berita-skadron-12-way-tuba-ujihelikopter-serbu-fennec-as-550-c3.html>, accessed on 03/07/2021.

Minarno, Supartono, \& Widjajanto, J. (2018). Pengaruh Pendidikan dan Pelatihan Terhadap Kemampuan Personel Skuadron Udara 800 Wing Udara 1 Puspenerbal. Jurnal Strategi Pertahanan Udara, 4(2), 25-46.

Prior, T., \& Roth, F. (2013). Disaster, Resilience and Security in Global Cities. Journal of Strategic Security, 6(2), 59-69. http://dx.doi.org/10.5038/1944-0472.6.2.5

Rani, O. L., Ekawati, \& Kurniawan, B. (2016). Analisis kepatuhan crew pesawat militer terhadap prosedur keselamatan penerbangan di pusat penerbangan Semarang. Jurnal Kesehatan Masyarakat, 4(3), 557-567.

Sebastian, E. (2015). Peningkatan peranan SDM pertahanan nasional guna menghadapi perang generasi keempat. Jurnal Pertahanan, 5(1),109-128. Doi: http://dx.doi.org/10.33172/jpbh.v5i1.351

Senayanpost.com. (2021). Jejak Hendropriyono di Balik Penemuan dan Pembangunan Lanudad Gatot Soebroto <https://www.senayanpost.com/jejak-hendropriyono-di-balik-penemuan-dan-pembangunan-lanudad-gatot-Soebroto>, accessed on 03/07/2021.

Setiawan, T. O. (2018). Peran Skadron Udara 8 TNI AU dalam operasi pengamanan daerah rawan di Indonesia. Jurnal Strategi Pertahanan Udara, 4(2), 87-104.

Soekanto, S. (2009). Peranan sosiologi suatu pengantar. Edisi Baru. Jakarta: Rajawali Pers.

Sofyan, Y., Sudarya, A., \& Lasmono. (2018). Pengaruh Pelatihan Simulator dan Kompetensi Terhadap Kinerja Perwira Penerbang Wing Udara 1 Pangkalan TNI AU Halim Perdanakusuma Jakarta. Jurnal Strategi Pertahanan Udara, 4(3), 63-74. 